\title{
Platelet function activity in black-motley calves during the dairy phase
}

\author{
Nadezhda V. Vorobyeva ${ }^{1,2}$ and Ilya N. Medvedev ${ }^{3, *}$ \\ ${ }^{1}$ South-West state University, Kursk 305040, Russia \\ ${ }^{2}$ All-Russian Research Institute of Physiology, Biochemistry and Nutrition of Animals, Institute village, Borovsk, 249013, Kaluga \\ region, Russia \\ ${ }^{3}$ Russian State Social University, Moscow 129226, Russia
}

\begin{abstract}
Platelet activity in cattle can change under the influence of many factors. Their assessment in the second phase of their early ontogenesis is of great interest, taking into account the breed of calves. The purpose of the work is to evaluate platelet activity in black-and-white breed dairy calves. The study was conducted on 41 calf of black-motley breed, which was obtained from healthy cows as a result of 2-3 pregnancies. The calves were examined on the 11 th, 15 th, 20th, 25 th and 30 th day of ontogenesis. The study used biochemical, hematological and statistical methods. In animals, an increase in platelet aggregation with all tested inductors was detected during the milk feeding phase. The number of discoid platelets in the blood of calves observed during the second phase of early ontogenesis decreased by $10.5 \%$. Moreover, the total number of active platelets increased by $24.0 \%$. The levels of small, as well as medium and large aggregates of platelets present in the blood also increased during the milk feeding phase by 28.6 and $27.3 \%$, respectively. This was achieved in the observed calves by an increase of $9.6 \%$ in the synthesis of thromboxane in platelets due to an increase in the activity of cyclooxygenase in them by $9.4 \%$ and thromboxane synthetase by $9.3 \%$. This was also influenced by the increase in the platelet content of adenosine phosphates and the increase in their secretion. The levels of actin and myosin in inactive calf platelets increased during the milk feeding phase by 9.7 and $13.2 \%$, respectively. In animals, an increase in the additional generation of actin and myosin was revealed during platelet aggregation by 11.1 and $9.8 \%$, respectively. It is clear that calves of the black-motley breed of dairy food are characterized by a certain increase in the activity of platelet aggregation and secretion. This provides them with a high degree of preservation of blood volume in case of damage to blood vessels. The growth of intravascular platelet activity in these calves also contributes to the creation of the necessary conditions to minimize blood loss and ensure homeostasis.
\end{abstract}

\section{Introduction}

As the functionality of the hemostatic system seriously identifies hemocirculation [1,2]. Great value in this belongs to platelets. Their hemostatic properties strongly govern the operation of microcirculation $[3,4]$ in all organisms $[5,6]$. Previously shown that platelet activity changes during ontogeny [7] and in aging [8,9], the development of dysfunctions [10,11], the development of pathology [12], the formation of pasopati $[13,14]$ and on the background of therapeutic effects [15-17]. However, many aspects of the functioning of platelets in cattle so far been studied very poorly. There are some works devoted to the platelets of these productive animals in the individual age groups [18]. These individual details do not allow having a holistic view on the issue and dictating the need to perform extensive research. The need for these works is due to the great importance of the functions of platelets for the flow of blood flow in the capillaries. It is clear that microcirculation affects the growth and development of animals is strong, thus realizing their productive potential [19]. Due to genetic differences between individual breeds of cattle and high physiological values of platelets activity in the realization of the potential productivity, it is necessary to evaluate the properties of thrombocytes in calves belonging to highly productive on the milk yield of black-motley breed in the second phase of their early ontogeny.

The goal is to evaluate the activity of platelets in calves' milk of black-motley breed.

\section{Materials and methods}

The research was conducted in strict accordance with ethical principles established by the European Convent on protection of the vertebrata used for experimental and other scientific purposes (adopted in Strasbourg March 18, 1986, and confirmed in Strasbourg June 15, 2006) and approved by the local ethic committee of All-

* Corresponding author: ilmedv1@yandex.ru 
Russian SII of Physiology, Biochemistry and Animals' feeding (Record №11, dated December 4, 2015).

The study was conducted on 41 calf black-and-white breed, which were obtained from healthy cows $2-3$ of pregnancy. All the calves were examined for the phase of milk feeding 5 times: 11, 15, 20, 25 and 30 day of life.

The determination of the intensity of the formation of thromboxane in platelets and evaluation of the activity of cyclooxygenase and thromboxane synthetase was performed in three sample transfer using the photoelectrocolorimeter [20]. In platelets was assessed by the levels of adenosine triphosphate (ATP) and adenosine diphosphate (ADP), the intensity of their secretion when introduced into the environment of collagen and number of actin and myosin in the protein composition of the cytoskeleton of intact and exposed to platelet activation in response to ADP [20].

The development period of platelet aggregation (AP) was found by visual micro-method [21], using as inductor $\operatorname{ADP}\left(0.5 \times 10^{-4} \mathrm{M}\right)$, collagen (dilution 1:2 primary suspension), thrombin $(0,125$ unit $/ \mathrm{ml})$, epinephrine $\left(5.0 \times 10^{-6} \mathrm{M}\right)$ and ristomycin $(0,8 \mathrm{mg} / \mathrm{ml})$ in plasma, which were standardized level of platelets $200 \times 10^{9}$ platelets. Intravascular platelet activity was assessed using phase-contrast microscopy [22]. Statistical processing of received information was made with the help of a program packet "Statistics for Windows v. 6.0", "Microsoft Excel". Differences in data were considered reliable in case $\mathrm{p}<0.05$.

\section{Results}

The number of platelet-disc cells in the blood of calves taken into the study during the phase of milk feeding decreased to $70.1 \pm 0.24 \%$. During the observation of them, the total number of active platelets in their blood increased by $24.0 \%$. The number of platelet aggregates of any size in their blood between 10 and 30 days of life increased by 28.6 and $27.3 \%$, respectively.

In dairy calves of black and white breed, an increase in the hemostatic properties of platelets was noted. Thus, in the examined calves, on the 11th day of life, AP occurred with collagen for $31.8 \pm 0.10 \mathrm{~s}$, then accelerating by 30 days of ontogenesis to $28.6 \pm 0.15 \mathrm{~s}$. A similar acceleration of antibodies was detected with ADP and ristomycin up to $36.5 \pm 0.09 \mathrm{~s}$ and $43.6 \pm 0.17 \mathrm{~s}$, respectively. For antibodies with thrombin and adrenaline, the time was also reduced to $48.7 \pm 0.11 \mathrm{~s}$ and $91.1 \pm 0.21 \mathrm{~s}$.

An important mechanism ensuring the acceleration of antibodies in black-motley breed milk calves is the enhancement of thromboxane synthesis in their platelets. This was indicated by an increase of $9.6 \%$ AP in a simple transfer sample. The basis of this in these calves was an increase in the activity of platelet cyclooxygenase and thromboxane synthetase. This was indicated by an increase in the recovery of antibodies in a collagenaspirin sample, which indirectly estimates the state of cyclooxygenase (by the end of the observation, $86.6 \pm 0.14 \%)$. The level of AP recovery in the collagen- imidazole test, which indirectly measures the activity of thromboxane synthetase in calf platelets, also increased and amounted to $44.8 \pm 0.16 \%$ on day 30 .

Initially, a low number of ATP and ADP of calves in platelets increased, reaching $5.96 \pm 0.012$ and $3.61 \pm 0.009$ $\mu \mathrm{mol} / 10^{9}$ platelets by 30 days of life. Under these conditions, their secretion from platelets between 10 and 30 days of life increased to $33.9 \pm 0.14$ and $44.8 \pm 0.13 \%$.

The amount of actin and myosin on day 11 in inactive calf platelets was $27.8 \pm 0.10$ and $13.6 \pm 0.13 \%$ of the total protein in the platelet. By the end of the observation, it amounted to $30.5 \pm 0.14$ and $15.4 \pm 0.16 \%$ of the total protein in the platelet. During the observation, the calves also had an increase in platelet aggregation of actin formation by $11.1 \%$ and myosin by $9.8 \%$.

\section{Discussion}

Recent studies have led to an understanding of the great biological significance of the dynamics of hematological parameters in humans and animals due to the fact that they reveal various aspects of the functioning of homeostasis [23, 24]. Given the great importance for the work of the body of calves of high-milk breeds, platelet activity in them is studied very poorly. This was the motivation for performing this study on calves of the black-motley breed of dairy food.

In the assessment of calves AP with collagen and ristomycin, a gradual increase in the adhesion of their platelets during the milk feeding phase was found. Obviously, this happened according to two mechanisms [25]. The first mechanism was revealed by the found acceleration of their aggregation with collagen. This should be associated with an increase in calf platelet membranes during the observation of the number of glycoproteins Ia-IIa and VI, which are collagen receptors.

The second mechanism for enhancing platelet adhesion in black-motley breed milk calves is an increase in the number of von Willebrand factor receptors (GPIb) on their surface with an increase in their blood concentration. This was indicated by the acceleration of AP found in the examined calves in response to ristomycin.

The accelerated platelet aggregation detected in calves of dairy black-motley breed undoubtedly gives a high degree of protection for their body from blood loss. Some acceleration of their antibodies to strong inducers (collagen and thrombin) is provided by a slight increase in the number of receptors for them on platelet membranes in combination with activation of phospholipase $\mathrm{C}$ and phosphoinositol pathway against the background of increased phosphorylation of proteins of their contractile system.

The activation of formation of inositol triphosphate calves in platelets is apparently ensured at this age by enhancing the release of $\mathrm{Ca}^{2+}$ from dense granules, which is a mechanism for stimulating self-assembly and reducing actomyosin [26]. 
Table 1. Platelet characteristics of black-motley calves of dairy nutrition

\begin{tabular}{|c|c|c|c|c|c|}
\hline \multirow{2}{*}{$\begin{array}{l}\text { Registrated } \\
\text { parameters }\end{array}$} & \multicolumn{5}{|c|}{ Age of black-motley calves, $n=41, M \pm m$} \\
\hline & 11 day & 15 day & 20 day & 25 day & 30 day \\
\hline $\begin{array}{l}\text { The number of ATP in platelets before secretion, } \\
\mu \mathrm{mol} / 10^{9} \text { platelets }\end{array}$ & $5.48 \pm 0.010$ & $5.55 \pm 0.016$ & $5.63 \pm 0.018$ & $5.75 \pm 0.015$ & $\begin{array}{c}5.96 \pm 0.012 \\
p<0.05\end{array}$ \\
\hline $\begin{array}{l}\text { The number of ADP in platelets before secretion, } \\
\mu \mathrm{mol} / 10^{9} \text { platelets }\end{array}$ & $3.27 \pm 0.009$ & $3.37 \pm 0.011$ & $3.45 \pm 0.007$ & $3.52 \pm 0.012$ & $\begin{array}{c}3.61 \pm 0.009 \\
\mathrm{p}<0.05\end{array}$ \\
\hline The severity of secretion ATP, $\%$ & $30.3 \pm 0.10$ & $31.0 \pm 0.13$ & $31.6 \pm 0.06$ & $32.8 \pm 0.10$ & $\begin{array}{c}33.9 \pm 0.14 \\
\mathrm{p}<0.05\end{array}$ \\
\hline The severity of ADP secretion, $\%$ & $40.4 \pm 0.10$ & $41.0 \pm 0.12$ & $42.1 \pm 0.15$ & $43.0 \pm 0.17$ & $\begin{array}{c}44.8 \pm 0.13 \\
p<0.05\end{array}$ \\
\hline $\begin{array}{l}\text { AP recovery level when conducting collagen- } \\
\text { aspirin test, } \%\end{array}$ & $79.2 \pm 0.08$ & $80.1 \pm 0.10$ & $80.8 \pm 0.08$ & $82.1 \pm 0.11$ & $\begin{array}{c}86.6 \pm 0.14 \\
\mathrm{p}<0.05\end{array}$ \\
\hline $\begin{array}{l}\text { AP recovery level when conducting } \\
\text { collagen-imidazole test, \% }\end{array}$ & $41.0 \pm 0.09$ & $41.8 \pm 0.14$ & $42.6 \pm 0.12$ & $43.1 \pm 0.09$ & $\begin{array}{c}44.8 \pm 0.16 \\
\mathrm{p}<0.05\end{array}$ \\
\hline AP level in a simple transfer sample, $\%$ & $30.3 \pm 0.08$ & $30.9 \pm 0.05$ & $31.7 \pm 0.06$ & $32.6 \pm 0.08$ & $\begin{array}{l}33.2 \pm 0.07 \\
\mathrm{p}<0.05\end{array}$ \\
\hline $\begin{array}{l}\text { The amount of actin in inactive platelets, } \% \text { of the } \\
\text { total protein in platelets }\end{array}$ & $27.8 \pm 0.10$ & $28.1 \pm 0.07$ & $28.8 \pm 0.05$ & $29.4 \pm 0.10$ & $\begin{array}{c}30.5 \pm 0.14 \\
\mathrm{p}<0.05\end{array}$ \\
\hline $\begin{array}{l}\text { The amount of actin in platelets with ADP- } \\
\text { aggregation, } \% \text { of total protein in platelets }\end{array}$ & $38.6 \pm 0.15$ & $39.0 \pm 0.17$ & $39.8 \pm 0.13$ & $41.6 \pm 0.15$ & $\begin{array}{c}42.9 \pm 0.13 \\
\mathrm{p}<0.05\end{array}$ \\
\hline $\begin{array}{l}\text { The amount of myosin in inactive platelets, } \% \text { of } \\
\text { the total protein in platelets }\end{array}$ & $13.6 \pm 0.13$ & $14.2 \pm 0.10$ & $14.8 \pm 0.09$ & $15.2 \pm 0.12$ & $\begin{array}{l}15.4 \pm 0.16 \\
\mathrm{p}<0.05\end{array}$ \\
\hline $\begin{array}{l}\text { The amount of myosin in platelets during ADP- } \\
\text { aggregation, } \% \text { of the total protein in platelets }\end{array}$ & $28.5 \pm 0.11$ & $28.9 \pm 0.10$ & $29.6 \pm 0.14$ & $30.0 \pm 0.12$ & $\begin{array}{c}31.3 \pm 0.13 \\
\mathrm{p}<0.05\end{array}$ \\
\hline AP development time with ADP, $\mathrm{s}$ & $39.8 \pm 0.18$ & $39.1 \pm 0.16$ & $38.4 \pm 0.10$ & $37.7 \pm 0.14$ & $\begin{array}{c}36.5 \pm 0.09 \\
\mathrm{p}<0.05\end{array}$ \\
\hline The development time of AP with collagen, $\mathrm{s}$ & $31.8 \pm 0.10$ & $31.2 \pm 0.16$ & $30.6 \pm 0.12$ & $\begin{array}{l}29.4 \pm 0.13 \\
\mathrm{p}<0.05\end{array}$ & $\begin{array}{c}28.6 \pm 0.15 \\
p<0.05\end{array}$ \\
\hline The development time of AP with thrombin, $\mathrm{s}$ & $52.7 \pm 0.12$ & $51.6 \pm 0.14$ & $50.5 \pm 0.09$ & $49.3 \pm 0.16$ & $\begin{array}{c}48.7 \pm 0.11 \\
\mathrm{p}<0.05\end{array}$ \\
\hline The development time of AP with ristomycin, $\mathrm{s}$ & $47.6 \pm 0.14$ & $46.8 \pm 0.10$ & $46.0 \pm 0.18$ & $45.2 \pm 0.12$ & $\begin{array}{c}43.6 \pm 0.17 \\
p<0.05\end{array}$ \\
\hline The development time of AP with adrenaline, $\mathrm{s}$ & $97.2 \pm 0.20$ & $96.2 \pm 0.17$ & $95.5 \pm 0.23$ & $94.0 \pm 0.19$ & $\begin{array}{c}91.1 \pm 0.21 \\
\mathrm{p}<0.05\end{array}$ \\
\hline Platelet-discocyte level, $\%$ & $77.5 \pm 0.14$ & $76.3 \pm 0.12$ & $74.1 \pm 0.16$ & $72.3 \pm 0.15$ & $\begin{array}{l}70.1 \pm 0.24 \\
\mathrm{p}<0.05\end{array}$ \\
\hline Sum of activated platelet forms, $\%$ & $22.5 \pm 0.10$ & $23.7 \pm 0.16$ & $\begin{array}{l}25.9 \pm 0.12 \\
\mathrm{p}<0.05\end{array}$ & $\begin{array}{c}26.7 \pm 0.14 \\
\mathrm{p}<0.01\end{array}$ & $\begin{array}{c}27.9 \pm 0.18 \\
\mathrm{p}<0.01\end{array}$ \\
\hline $\begin{array}{l}\text { The number of small platelet aggregates, per } 100 \\
\text { free platelets }\end{array}$ & $3.5 \pm 0.11$ & $3.6 \pm 0.09$ & $\begin{array}{l}3.8 \pm 0.06 \\
\mathrm{p}<0.05\end{array}$ & $\begin{array}{l}4.1 \pm 0.08 \\
\mathrm{p}<0.01\end{array}$ & $\begin{array}{l}4.5 \pm 0.07 \\
p<0.01\end{array}$ \\
\hline $\begin{array}{l}\text { The number of medium and large platelet } \\
\text { aggregates per } 100 \text { free platelets }\end{array}$ & $0,11 \pm 0,018$ & $0.11 \pm 0.015$ & $\begin{array}{l}0.12 \pm 0.016 \\
\mathrm{p}<0.05\end{array}$ & $\begin{array}{c}0.13 \pm 0.023 \\
\mathrm{p}<0.01\end{array}$ & $\begin{array}{c}0.14 \pm 0.020 \\
\mathrm{p}<0.01\end{array}$ \\
\hline
\end{tabular}

Note: $\mathrm{p}-$ is the reliability of the dynamics of indicators in relation to 11 days of age.

Weak stimulants of platelet aggregation (ADP and adrenaline) in black-motley breed milk calves stimulated platelet aggregation, which accelerated with age. This was undoubtedly associated with an increase in the number of receptors for them on platelets, an increase in the expression of fibrinogen receptors (GPIIb-IIIa), and an increase in the activity of phospholipase $A_{2}$ in them. The intensification of the release of phospholipids from arachidonic acid membranes provided enhanced synthesis of thromboxane $A_{2}$ [27]. The increase in the activity of cyclooxygenase and thromboxanesynthetase, found in black and white breed calves, also stimulated the synthesis of thromboxane $A_{2}$. This was confirmed by transfer tests, which showed an increase in the activity of cyclooxygenase and thromboxane synthetase in the blood plates of dairy calves. Another important mechanism for accelerating AP in dairy calves is the increase in actinogenesis and myosin formation under conditions of the appearance of an aggregation inducer in the plasma and increased secretion of ATP and ADP calf platelet granules from the platelets.

To estimate the start of platelet activation in calves milk supply black-and-white was clarified by intravascular platelet activity during vasovasostomy microscopy. These calves were found the increase in the number of active platelets in the field. It talked about the increase in the sensitivity of platelets to aggregation of stimulants. The increase of intravascular platelet activity, also spoke about increasing availability to the blood collagen of the blood vessels, including because of the rise in their blood svobodnozhivushchikh trombotsitarnyh units. It also pointed to the increase in 
the blood of the calves-dairy producers of black-motley breed of other inducers of platelet aggregation (ADP, thrombin, epinephrine) [28]. Gain from the observed calves of platelet aggregation leads to increased level of active forms and their units of any size in the blood. This is an important mechanism eliminating the risk of bleeding in the absence of blockade functionally required number of microvascular platelet aggregates and maintains the optimum level of physiological processes of platelet-vascular interactions. Found intravascular aggregation of blood platelets in calves milk of black-motley breed indicates high activity adequate adhesion and aggregation properties of blood platelets and suggests that they are physiologically sufficient level of disaggregation, apparently due to the high density of receptors antiplatelet agents on the membranes of platelets.

\section{Conclusion}

For calves' milk of black-motley breed is characterized by the increased activity of platelets. It maintains homeostasis by ensuring that conditions to minimize their bleeding, while maintaining optimal conditions for microcirculation in the tissues. This ensures they gain in the physiologically acceptable limits of the activity of the mechanisms of platelet adhesion, aggregation and secretion. The increased intravascular activity of platelets in calves of black-motley breed during the phase of milk feeding significantly ensures the preservation of homeostasis under normal condition of blood flow in the vessels and optimum metabolism in their muscles and internal organs, which creates conditions for the normal growth and development of calves of this breed.

\section{References}

1. V.I. Maksimov, S.Yu. Zavalishina, A.V. Parakhnevich, E.N. Klimova, N.A. Garbart, A.A. Zabolotnaya, Yu.I. Kovalev, T.Yu. Nikiforova, E.I. Sizoreva, Physiological Dynamics of Microrheological Characteristics Of Erythrocytes In Piglets During The Phase Of Milk Nutrition, Res. J. of Pharmaceut., Biolog. and Chemical Sci., 9(5), 454-459 (2018)

2. E.S. Tkacheva, S.Yu. Zavalishina, Physiology of Platelet Hemostasis In Piglets During The Phase Of Newborns, Res. J. of Pharmaceut., Biolog. and Chemical Sci., 9(5), 1912-1918 (2018)

3. S.Yu. Zavalishina, Functional Properties Of Anticoagulation And Fibrinolysis In Calves Of Plant Nutrition, Res. J. of Pharmaceut., Biolog. and Chemical Sci., 9(5), 1082-1087 (2018)

4. S.Yu. Zavalishina, Functional Features Of Platelets In Newborn Calves With Iron Deficiency, Res. J. of Pharmaceut., Biolog. and Chemical Sci., 9(5), 1153-1158 (2018)

5. S.Yu. Zavalishina, Physiological Features of Vascular Hemostasis In Calves Of Dairy-Vegetative
Food, Res. J. of Pharmaceut., Biolog. and Chemical Sci., 9(5), 1137-1143 (2018)

6. E.S. Tkacheva, S.Yu. Zavalishina, Physiological Features Of Platelet Aggregation In Newborn Piglets, Res. J. of Pharmaceut., Biolog. and Chemical Sci., 9(5), 36-42 (2018)

7. S.Yu. Zavalishina, Functional Properties of Hemocoagulation In Calves Of Dairy Nutrition, Res. J. of Pharmaceut., Biolog. and Chemical Sci., 9(5), 1016-1022 (2018)

8. S.Yu. Zavalishina, Functioning Of Platelets In Milk And Vegetable Nutrition Calves, Res. J. of Pharmaceut., Biolog. and Chemical Sci., 9(5), 943-949 (2018)

9. S.Yu. Zavalishina, Deficiency Of Iron As A Cause Of Dysfunction In Calves And Piglets, Res. J. of Pharmaceut., Biolog. and Chemical Sci., 9(5), 978-983 (2018)

10. L.V. Korepanova, O.S. Starostina, S.D. Batanov, The Blood as an indicator of the interior features of the hybrid animals, Husbandry, 10, 26-28 (2015)

11. A.S. Shitikova, Trombotsitopatii of congenital and acquired (Saint Petersburg, 2008)

12. S.Yu. Zavalishina, Functional Properties of Coagulation Hemostasis In Calves During The Phase Of Dairy-Vegetative Nutrition, Res. J. of Pharmaceut., Biolog. and Chemical Sci., 9(5), 784-790 (2018)

13. S.Yu. Zavalishina, Functional Activity of Anticoagulant System In Calves During Early Ontogeny, Res. J. of Pharmaceut., Biolog. and Chemical Sci., 9(5), 837-843 (2018)

14. S.Yu. Zavalishina, Functional Properties Of Fibrinolysis In Calves Of The First Year Of Life, Res. J. of Pharmaceut., Biolog. and Chemical Sci., 9(5), 870-876 (2018)

15. E.N. Lazareva, M.A. Mamatsuev, N.N. Lomakin, $A$ modern take on the morphofunctional features of platelets, Natural Sci., 3, 36-42 (2005)

16. A.A. Bikbulatova, Functional Features of Microcirculatory Processes In Obese Women Against A Background Of Long Daily Wearing Of Corrective Clothing, Res. J. of Pharmaceut., Biolog. and Chemical Sci., 9(6), 785-793 (2018)

17. S.Yu. Zavalishina, Functioning Of Mechanisms of Hemocoagulation Restriction In Calves At Change Of Methods Of Nutrition, Res. J. of Pharmaceut., Biolog. and Chemical Sci., 9(5), 800-806 (2018)

18. S.Yu. Zavalishina, Physiological Features Of Coagulation In Calves Of Plant Nutrition, Res. J. of Pharmaceut., Biolog. and Chemical Sci., 9(5), 899-904 (2018)

19. G.C. White, R. Rompietti, Platelet secretion: indiscriminately spewed forth or highly orchestrated? J. Thromb. Haemost, 5, 2009-2016 (2007)

20. M. Levi, Platelets. Crit. Care. Med., 33, 523-525 (2005) 
21. N.V. Vorobyeva, G.S. Mal, S.Yu. Zavalishina, T.I. Glagoleva, I.I. Fayzullina, Influence Of Physical Exercise On The Activity Of Brain Processes, Res. J. of Pharmaceut., Biolog. and Chemical Sci., 9(6), 240-244 (2018)

22. S.Yu. Zavalishina, Functional Activity Of Plasma Hemostasis In Neonatal Calves With Iron Deficiency, Who Received Ferroglucin And Glycopin, Res. J. of Pharmaceut., Biolog. and Chemical Sci., 9(5), 1186-1191 (2018)

23. E.S. Tkacheva, S.Yu. Zavalishina, Physiological Aspects Of Platelet Aggregation In Piglets Of Milk
Nutrition, Res. J. of Pharmaceut., Biolog. and Chemical Sci., 9(5), 74-80 (2018)

24. S.Yu. Zavalishina, Functional Activity Of Thrombocytes In Newborn Calves, Res. J. of Pharmaceut., Biolog. and Chemical Sci., 9(5), 919-924 (2018)

25. S.Yu. Zavalishina, Anti-Coagulant And Fibrinolytic Activity Of Blood Plasma In Healthy Calves Of Dairy-Vegetative Nutrition, Res. J. of Pharmaceut., Biolog. and Chemical Sci., 9(5), 753-758 (2018) 